\title{
Integrated application of phosphorus (P) and phosphate solubilizing bacteria (PSB) improve maize yield
}

\author{
Fazlullah $^{1}$, Muhammad Adnan ${ }^{1,2 *}$, Shah Fahad ${ }^{1}$, Saadia Iqbal ${ }^{3}$, \\ Muhammad Arshad ${ }^{4}$, Dost Muhammad ${ }^{5}$, Fazli Wahid ${ }^{1}$, Akif
} Hussain ${ }^{1}$, Muhammad Roman ${ }^{6}$, Rainaz Perveez ${ }^{7}$ and Muhammad Noor ${ }^{1}$

1. Department of Agriculture, University of Swabi-Pakistan

2. Department of Soil, Plant and Microbial Sciences, Michigan State University, East Lansing-USA

3. Department of Agriculture Chemistry, The University of Agriculture Peshawar-Pakistan

4. Mountain Agriculture Research Center, Gilgit-Bultistan-Pakistan

5. Department of Soil and Environmental Sciences, The University of Agriculture Peshawar-Pakistan

6. Department of Botany, University of Chitral-Pakistan

7. Department of Botany, Government Girls Degree Collage Dargai, Malakand-Pakistan

*Corresponding author's email: madnanses@gmail.com

Citation

Fazlullah, Muhammad Adnan, Shah Fahad, Saadia Iqbal, Muhammad Arshad, Dost Muhammad, Fazli Wahid, Akif Hussain, Muhammad Roman, Rainaz Perveez and Muhammad Noor. Integrated application of phosphorus (p) and phosphate solubilizing bacteria (psb) improve maize yield. Pure and Applied Biology. Vol. 7, Issue 2, pp494-499. http://dx.doi.org/10.19045/bspab.2018.70062

\begin{tabular}{llll}
\hline \hline Received: 21/02/2018 & Revised: 04/04/2018 & Accepted: 07/04/2018 & Online First: 14/04/2018 \\
\hline
\end{tabular}

\section{Abstract}

Phosphorous deficiency in soils has become the prominent limiting factor for plant and root growth. A field experiment was laid out at theagronomic researchfarm of Department of Agriculture, University of Swabi to assess the response of maize to P rates $(60,90$ and $120 \mathrm{Kg}$ $\mathrm{P}_{2} \mathrm{O}_{5}$ ha $^{-1}$ ) and PSB (with and without PSB). Two factorial randomized complete block design (RCBD) with three replications was used for this experiment. With the increasing P from 60 to $120 \mathrm{Kg} \mathrm{P}_{2} \mathrm{O}_{5}$ ha $^{-1}$ both with and without PSB inoculation plant height, 1000 grains weight, grain and biological yield were significantly increased. Similarly, PSB inoculation (on average) meaningfully increased plant height, 1000 grains weight, grain and biological yield by 11, 1, 10 and 6\% respectively, at all $\mathrm{P}$ level compared to un-inoculated control. Significant interactive effect of PSB and $\mathrm{P}$ over mentioned yield attributes exhibited that PSB application can reduce dependence on chemical P fertilizer up to $30 \mathrm{Kg} \mathrm{P}_{2} \mathrm{O}_{5} \mathrm{ha}^{-1}$ when $\mathrm{P}$ is applied from SSP. Thus it may be suggested that PSB should be applied with $90 \mathrm{Kg} \mathrm{P}_{2} \mathrm{O}_{5}$ ha $^{-1}$ chemical $\mathrm{P}$ fertilizer for efficient $P$ utilization and profitable crop yield.

Keywords: Grain yield; Maize; Phosphorus; Phosphate solubilizing bacteria

Introduction

Maize (Zea mays L.) belongs to family Poaceae and is grown inspring as well as summer season in Pakistan. In Pakistan it is the third important cereal crop after wheat and rice.It is high economic crop and has great significance for developing countries like Pakistan where population is incessantly increasing. [1].Total cultivated area of maize is $140 \mathrm{M}$ ha with a production around $420 \mathrm{M}$ tons worldwide [2].The area under maize cultivation in Pakistan and Khyber Pakhtunkhwa was $935.1 \mathrm{Kg} \mathrm{ha}^{-1}$ and $421.9 \mathrm{Kg} \mathrm{ha}^{-1}$, with production of 
3261.5 $\mathrm{Kg} \mathrm{ha}^{-1}$ tons and $752.2 \mathrm{Kg} \mathrm{ha}^{-1}$ tons, and the average yields of $3488 \mathrm{Kg} \mathrm{ha}^{-1}$ and $1135 \mathrm{~kg} \mathrm{ha}^{-1}$ respectively [3]. Khyber Pakhtunkhwa and Punjab contribute 68\% and $30 \%$ of the total production, respectively; while Sindh and Balochistan contribute a very a small percentage i.e. 2$3 \%$ [4]. Maize grains counted a great importance on the basis of their Pharmaceutical and industrial usage [5].

Phosphorus (P) is the second important plant essitional nutrient which effects on plant growth by inducing the basic metabolic processes such as cell splitting up and enlargement, energy carrying (ATP, ADP), macromolecular biosynthesis, photosynthesis and respiration [6].Phosphorus applied in the form of organic and inorganic fertilizers to the soil. However, a large portion of soluble inorganic phosphate applied to the soil as chemical fertilizer is immobilized rapidly and becomes unavailable to plants [7]. Phosphorus ranges from 0.02 to $0.05 \%$ ( $\mathrm{w}=\mathrm{w})$ in the soil; [8], from this values is just $0.1 \%$ is available to plants [9]. On which $\mathrm{P}$ sufficient requirement to plant not be accessible thus need to be applied to soils as inorganic soluble P fertilizers; a small part of these applied inorganic $\mathrm{P}$ fertilizer only $1 \%$ uptake by plants and the rest $(\sim 99$ $\%)$ is rapidly transformed into unsolvable complexes [10]in alkaline soils [11]. These cation complexes precipitate about $80 \%$ of applied inorganic $\mathrm{P}$ fertilizer. While, the recapture efficacy of $\mathrm{P}$ is less than $20 \%$ of the added $\mathrm{P}$ in the world soils [12].

Microorganisms are take an integral part in transformation, solublization and organic matter decomposition processes which are effective in releasing $\mathrm{P}$ from inorganic and organic sources of $P$ [13]. Hence, soil microorganisms play a vital role in $\mathrm{P}$ availability to the plants applied to inorganic and organic sources [14]. In particular, P-solubilizing bacteria (PSB) are reported to play an important role in enhancing the $\mathrm{P}$ efficiency of both natural and applied $\mathrm{P}$ and improving the productivity of field crops [11]. Nutrition of $\mathrm{P}$ is improve by PSB through the release of low-molecular-weight organic acids [15], which through their hydroxyl and carboxyl groups chelate the cations bound to phosphate, thereby converting it into soluble forms[16].

As most of our soils in Pakistan are alkaline and calcareous in nature, due to which bio availability of $\mathrm{P}$ is a major problem in our soil. That's why the present study was initiated with the following objectives to evaluate the impact of PSB and P on the growth and yield of maize crop.

\section{Materials and methods}

\section{Experimental procedure}

A field experiment was conducted at the agronomic research farm of Department of Agriculture, University of Swabi to evaluate the combine impact of $\mathrm{P}$ fertilization $\left(60,90\right.$ and $120 \mathrm{Kg}_{2} \mathrm{O}_{5}$ ha $^{-}$ ${ }^{1}$ )and PSB inoculation (control and inoculated) on the yield of maize crop. The experiment was design in two factorial randomize complete block design (RCBD) with three replication. The soil of the experimental field was silt loam in texture, non- saline, alkaline and calcareous in nature and low in organic matter and ABDTPA extractable P (Table 1).

Table 1.Physio-chemical properties of composite sample

\begin{tabular}{|c|c|c|}
\hline Property & Concentration & Units \\
\hline Textural class & Silt loam & - \\
\hline $\mathrm{EC}$ & 1.75 & $\mathrm{dSm}^{-1}$ \\
\hline $\mathrm{pH}$ & 7.4 & - \\
\hline Organic matter & 0.74 & $\%$ \\
\hline Lime & 13.6 & $\%$ \\
\hline $\mathrm{P}($ AB-DTPA extractable) & 2.24 & $\mathrm{mg} \mathrm{kg}^{-1}$ \\
\hline
\end{tabular}


PSB inoculums was obtained from Department of Microbiology University of Hazara. The seed of maize verity Azamwas inoculated with PSB as per proposed treatment via using stander inoculation procedure. For this purpose maize seed were placed in $10 \%$ sugar solution and then amended with PSB inoculums. Seeds were shade dried. P was applied at the rate of 60 , 90 and $120 \mathrm{P}_{2} \mathrm{O}_{5} \mathrm{Kg} \mathrm{ha}^{-1}$ according to the treatment structure of the experiment using SSP as a source. Inoculated maize seed were sown at the rate of $25 \mathrm{Kg} \mathrm{ha}^{-1}$ while using a row to row and plant to plant distance of 75 and $50 \mathrm{~cm}$ respectively. Basal dose of $\mathrm{N}$ and $\mathrm{K}$ was applied at the rate of 150 and $90 \mathrm{Kg} \mathrm{ha}^{-1}$ through Urea and SOP fertilizers. Normal recommended cultural practices were followed throughout the growing season.

\section{Agronomic parameters}

Plant height was recorded in $\mathrm{cm}$ from the base of the plant to the base of flag leaf with the help of meter rod. The data were calculated as the average of five randomly selected plants from each row.Thousand grains weight in $g$ was taken by weighting 1000 grains selected from every pot after sun drying. Biological yield per hectare was taken by weighing the total harvest obtained from each treatment plot after sun drying the biomass and was converted into $\mathrm{kg} \mathrm{ha}^{-1}$. Grain yield per hectare was taken by weighing the grains obtained from each treatment plot after sun drying the grains and was converted into $\mathrm{kg} \mathrm{ha}^{-1}$.

\section{Statistical analysis}

The data was analyzedfor Analysis of Variance (ANOVA) according to the procedure of Steel and Torrie [17]. After getting the significant variations for various studied parameters, the means for each parameter were further separated and compared by using the least significant difference (LSD) test at 5\% level of probability.

\section{Results and discussion}

A field experiment was conducted at the Research Farm of Department of Agriculture, University of Swabi. The aim of this experiment was to evaluate the impact of phosphatic fertilizers and PSB on growth and yield of maize crop. The results obtained in this experiment are as follow:

\section{Plant height}

Upon ANOVA result indicated that P, PSB inoculation and their interaction significantly affected plant height $\mathrm{cm}$ of maize (Table 2). It was exhibited by the result that PSB inoculation improved maize plant height over un inoculated treatment. Phosphorus applied at the rate of $120 \mathrm{~kg} \mathrm{ha}^{-}$ ${ }^{1}$ produced plant height of $166.82 \mathrm{~cm}$ which was significantly higher than that of $90 \mathrm{~kg}$ $\mathrm{ha}^{-1}$ where the lowest was observed for 60 $\mathrm{kg} \mathrm{ha}^{-1}$. The interaction effect of PSB and P indicated that $P$ applied at the rate of $120 \mathrm{~kg}$ $\mathrm{ha}^{-1}$ along with PSB produced taller plants while $60 \mathrm{~kg} \quad \mathrm{P}_{2} \mathrm{O}_{5} \mathrm{ha}^{-1}$ without PSB produced dwarf plant. $\mathrm{P}$ applied at the rate of $60 \mathrm{~kg} \mathrm{P}_{2} \mathrm{O}_{5} \mathrm{ha}^{-1}$ with PSB produced statistically similar plant height to that of 90 $\mathrm{kg} \mathrm{P}_{2} \mathrm{O}_{5} \mathrm{ha}^{-1}$ with and without PSB and 120 $\mathrm{kg} \mathrm{P}_{2} \mathrm{O}_{5}$ ha $^{-1} \mathrm{P}$ without PSB. These result demonstrated that PSB inoculation can reduce or may minimize dependence on chemical P fertilizer up to $100 \%$ under exist soil and climatic conditions.

Our results are is agreement to those of [18], who also reported that plant height improves with PSB inoculation over $27 \%$. PSB inoculation improves the availability of minerals content and nutrients which in result promotes plant growth, increase Phosphorus uptake and photosynthesis.

\section{Grain weight}

Result indicated that $\mathrm{P}$ levels, PSB inoculation and their interaction significantly affected 1000 grains weight (Table 3). It was exhibited by the result that PSB inoculation improved maize 1000 grain weight over un inoculated treatment. Phosphorus applied at the rate of $120 \mathrm{~kg}$ $\mathrm{P}_{2} \mathrm{O}_{5} \mathrm{ha}^{-1}$ produced 1000 grain weight of $307.13 \mathrm{~g}$ which was significantly higher than that of $90 \mathrm{~kg} \mathrm{P}_{2} \mathrm{O}_{5} \mathrm{ha}^{-1}$ where the lowest was observed for $60 \mathrm{~kg} \mathrm{P}_{2} \mathrm{O}_{5} \mathrm{ha}^{-1}$. The combine effect of PSB and P indicated that $\mathrm{P}$ applied at the rate of $120 \mathrm{~kg} \mathrm{ha}^{-1}$ along with PSB showed heaver grains 
while $\mathrm{P}$ applied at the rate of $60 \mathrm{~kg} \mathrm{P}_{2} \mathrm{O}_{5} \mathrm{ha}^{-}$ ${ }^{1}$ without PSB produced lighter. $\mathrm{P}$ applied at the rate of $60 \mathrm{~kg} \mathrm{P}_{2} \mathrm{O}_{5} \mathrm{ha}^{-1}$ with PSB produced statistically similar 1000 grain weight to that of $90 \mathrm{~kg} \mathrm{P}_{2} \mathrm{O}_{5} \mathrm{ha}^{-1} \mathrm{P}$ with and without PSB and $120 \mathrm{~kg} \mathrm{P}_{2} \mathrm{O}_{5} \mathrm{ha}^{-1} \mathrm{P}$ without PSB. These result proved that PSB inoculation can decline the use of chemical $P$ fertilizer up to $100 \%$ under exist soil and climatic conditions.

Table 2. Plant height of maize (cm) as affected by $P$ levels and PSB inoculation

\begin{tabular}{|c|c|c|c|}
\hline \multirow{2}{*}{$\begin{array}{c}\text { Phosphorus } \\
\left(\text { Kg ha }^{-1}\right)\end{array}$} & \multicolumn{2}{|c|}{ Inoculation } & \multirow{2}{*}{ Mean } \\
\cline { 2 - 3 } & With PSB & Without PSB & \\
\hline $\mathbf{6 0}$ & $150.10 \mathrm{~cd}$ & $143.60 \mathrm{e}$ & $146.85 \mathrm{c}$ \\
\hline $\mathbf{9 0}$ & $159.57 \mathrm{~b}$ & $146.30 \mathrm{de}$ & $152.93 \mathrm{~b}$ \\
\hline $\mathbf{1 2 0}$ & $181.40 \mathrm{a}$ & $152.23 \mathrm{c}$ & $166.82 \mathrm{a}$ \\
\hline Mean & $163.69 \mathrm{a}$ & $147.38 \mathrm{~b}$ & -------------- \\
\hline
\end{tabular}

$\operatorname{LSD}(\alpha=0.05) \mathrm{P}=3.7295, \mathrm{PSB}=3.0451$ and $\mathrm{PSB} \times \mathrm{P}=5.2743$, Mean with different liters in each row and column are significantly $(\alpha=0.05)$ different from each other

Table 3.1000 grain weight of maize (g) as affected by P levels and PSB inoculation

\begin{tabular}{|c|c|c|c|}
\hline $\begin{array}{c}\text { Phosphorus } \\
\left.\mathbf{( K g ~ h a}^{-1}\right)\end{array}$ & \multicolumn{2}{|c|}{ Inoculation } & \multirow{2}{*}{ Mean } \\
\cline { 2 - 3 } & With PSB & Without PSB & \\
\hline $\mathbf{6 0}$ & $293.00 \mathrm{c}$ & $288.80 \mathrm{c}$ & $290.90 \mathrm{c}$ \\
\hline $\mathbf{9 0}$ & $300.33 \mathrm{~b}$ & $293.40 \mathrm{c}$ & $296.87 \mathrm{~b}$ \\
\hline $\mathbf{1 2 0}$ & $306.00 \mathrm{a}$ & $308.27 \mathrm{a}$ & $307.13 \mathrm{a}$ \\
\hline Mean & $299.78 \mathrm{a}$ & $296.82 \mathrm{~b}$ & ------------ \\
\hline
\end{tabular}

$\operatorname{LSD}(\alpha=0.05) \mathrm{P}=3.2808, \mathrm{PSB}=2.6788$ and $\mathrm{PSB} \times \mathrm{P}=4.6398$ Mean with different liters in each row and column are significantly $(\alpha=0.05)$ different from each other

\section{Biological yield $\left(\mathrm{Kg} \mathrm{ha}^{-1}\right)$}

Result regarding the effect of PSB, $\mathrm{P}$ and their interaction on biological yield is presented (Table 4). Upon analysis of various result indicated that $\mathrm{P}$, PSB inoculation and their interaction significantly affected biological yield of maize. It was showed by the result that PSB inoculation improved maize biological yield over un inoculated treatment. Phosphorus applied at the rate of $120 \mathrm{~kg}$ $\mathrm{P}_{2} \mathrm{O}_{5}$ ha $^{-1}$ produced biological yield of 7134 $\mathrm{kg} \mathrm{ha}^{-1}$ which was significantly higher than that of $90 \mathrm{~kg} \mathrm{P}_{2} \mathrm{O}_{5} \mathrm{ha}^{-1}$ where the lowest was observed for $60 \mathrm{~kg} \mathrm{P}_{2} \mathrm{O}_{5} \mathrm{ha}^{-1}$. The interaction effect of PSB and $\mathrm{P}$ demonstrated that $\mathrm{P}$ applied at the rate of $120 \mathrm{P}_{2} \mathrm{O}_{5} \mathrm{~kg} \mathrm{ha}^{-1}$ along with PSB produced highest by which $\mathrm{P}$ applied at the rate of 60 $\mathrm{kg} \mathrm{P}_{2} \mathrm{O}_{5}$ ha $^{-1}$ without PSB produced lowest. $\mathrm{P}$ applied at the rate of $60 \mathrm{~kg} \mathrm{P}_{2} \mathrm{O}_{5} \mathrm{ha}^{-1}$ with PSB produced statistically similar biological yield to that of $90 \mathrm{~kg} \mathrm{P}_{2} \mathrm{O}_{5} \mathrm{ha}^{-1} \mathrm{P}$ with and without PSB and $120 \mathrm{~kg} \mathrm{P}_{2} \mathrm{O}_{5}$ ha $^{-}$ ${ }^{1} \mathrm{P}$ without PSB. These result demonstrated that PSB inoculation can reduce or may minimize dependence on chemical $P$ fertilizer up to a maximum of $100 \%$ under exist soil and climatic conditions.

Our results are is agreement to [19] who also concluded in his experiment that PSB inoculation along with Phosphorus fertilizers improved biological yield of plants over $30-40 \%$. PSB inoculation can minimize use of chemical fertilizers and also improves the biological yield of plants. 
Table 4.Biological yield $\left(\mathrm{Kg} \mathrm{ha}^{-1}\right)$ of maize as affected by P levels and PSB inoculation

\begin{tabular}{|c|c|c|c|}
\hline \multirow{2}{*}{$\begin{array}{c}\text { Phosphorus } \\
\left(\text { Kg ha }^{-1}\right)\end{array}$} & \multicolumn{2}{|c|}{ Inoculation } & \multirow{2}{*}{ Mean } \\
\cline { 2 - 3 } & With PSB & Without PSB & \\
\hline $\mathbf{6 0}$ & $6845.7 \mathrm{~b}$ & $6093.7 \mathrm{c}$ & $6469.7 \mathrm{c}$ \\
\hline $\mathbf{9 0}$ & $6997.0 \mathrm{ab}$ & $6753.0 \mathrm{~b}$ & $6875.0 \mathrm{~b}$ \\
\hline $\mathbf{1 2 0}$ & $7241.7 \mathrm{a}$ & $7027.3 \mathrm{ab}$ & $7134.5 \mathrm{a}$ \\
\hline Mean & $7028.1 \mathrm{a}$ & $6624.7 \mathrm{~b}$ & ------------- \\
\hline
\end{tabular}

LSD $(\alpha=0.05) \mathrm{P}=197.08, \mathrm{PSB}=160.91$ and $\mathrm{PSB} \times \mathrm{P}=278.71$ Mean with different liters in each row and column are significantly $(\alpha=0.05)$ different from each other

\section{Grain yield $\left(\mathrm{Kg} \mathrm{ha}^{-1}\right)$}

Our findings regarding the response of grain yield to P, PSB and their interaction present in (Table 5). Upon analysis of various result showed that $\mathrm{P}$, PSB inoculation and their interaction significantly affected grain yield $\left(\mathrm{Kg} \mathrm{ha}^{-1}\right)$ of maize. It was exhibited by the result that PSB inoculation improved maize grain yield over un inoculated treatment. Phosphorus applied at the rate of $120 \mathrm{~kg} \mathrm{ha}^{-}$ ${ }^{1}$ produced grain yield of $3521.1 \mathrm{~kg} \mathrm{ha}^{-1}$ which was significantly higher than that of $90 \mathrm{~kg} \mathrm{ha}^{-1}$ where the lowest was observed for $60 \mathrm{~kg} \mathrm{ha}^{-1}$. The interaction effect of PSB and $\mathrm{P}$ indicated that $\mathrm{P}$ applied at the rate of $120 \mathrm{~kg} \mathrm{ha}^{-1}$ along with PSB produced highest and $\mathrm{P}$ applied at the rate of $60 \mathrm{~kg}$ ha $^{-1}$ without PSB produced lowest. P applied at the rate of $60 \mathrm{~kg} \mathrm{P}_{2} \mathrm{O}_{5} \mathrm{ha}^{-1}$ with PSB produced statistically similar grain yield to that of 90 and $120 \mathrm{~kg} \mathrm{ha}^{-1} \mathrm{P}$ without PSB. These result demonstrated that PSB inoculation can reduce or may minimize dependence on chemical $\mathrm{P}$ fertilizer up to $100 \%$ under exist soil and climatic conditions.

Our results are is agreement to [12] also studied that PSB inoculation with phosphorus can improve grain yield of plants over $17.24,12.50$ and $15.63 \%$ and $4.56,5.29$ and $5.22 \%$ at 30,60 and $90 \mathrm{~kg} \mathrm{P}$ $\mathrm{ha}^{-1}$. PSB inoculation improves the growth and yield of plants, photosynthesis and microbial activity which in result shows significant interaction of PSB and Phosphorus fertilizers.

Table 5.Grain yield $\left(\mathrm{kg} \mathrm{ha}^{-1}\right)$ of maize as affected by P levels and PSB inoculation

\begin{tabular}{|c|c|c|c|}
\hline \multirow{2}{*}{ Phosphorus $\left(\mathrm{Kg} \mathrm{ha}^{-1}\right)$} & \multicolumn{2}{|c|}{ Inoculation } & \multirow{2}{*}{ Mean } \\
\cline { 2 - 3 } & With PSB & Without PSB & \\
\hline $\mathbf{6 0}$ & $3140.5 \mathrm{c}$ & $2923.7 \mathrm{~d}$ & $3032.1 \mathrm{c}$ \\
\hline $\mathbf{9 0}$ & $3358.0 \mathrm{~b}$ & $3027.9 \mathrm{~cd}$ & $3192.9 \mathrm{~b}$ \\
\hline $\mathbf{1 2 0}$ & $3717.9 \mathrm{a}$ & $3324.4 \mathrm{~b}$ & $3521.1 \mathrm{a}$ \\
\hline Mean & $3405.4 \mathrm{a}$ & $3092.0 \mathrm{~b}$ & -------------- \\
\hline
\end{tabular}

LSD $(\alpha=0.05) \mathrm{P}=83.266, \mathrm{PSB}=67.986$ and $\mathrm{PSB} \times \mathrm{P}=117.76 \mathrm{Mean}$ with different liters in each row and column are significantly $(\alpha=0.05)$ different from each other

\section{Conclusions and recommendations}

PSB inoculation, $\mathrm{P}$ fertilization and their interaction significantly improved plant height, 1000 grains weight, grain and biological yield. Highest grain and biological yield of maize was observed at $120 \mathrm{~kg} \mathrm{P}_{2} \mathrm{O}_{5} \mathrm{ha}^{-1}$ applied with PSB. Furthermore, PSB inoculation may reduce the use of chemical P fertilizer up to $30 \mathrm{~kg}$ $\mathrm{ha}^{-1}$. Thus it is advised that, maize seed must be inoculated with PSB along with $90 \mathrm{~kg}$ $\mathrm{P}_{2} \mathrm{O}_{5} \mathrm{ha}^{-1}$ for obtaining profitable yield of maize in agro-climatic conditions of Swabi.

Authors' contributions

Conceived and designed the experiments: $\mathrm{M}$ Adnan, Performed the experiments: Fazlullah \& A Hussain, Analyzed the data: M Noor, S Fahad \& S Iqbal, Contributed materials/ analysis/ tools: M Arshad, D Muhammad \& F Wahid, M Roman \& R 
Perveez, Wrote the paper: Fazlullah, M Adnan \& A Hussain.

\section{References}

1. PARC (2007)

http://www.pakistan.com,allabout/crops/ maize. Pakistan Agricultural Research Council, Islamabad.

2. Reddy MS, Kumar S, Babita K \& Reddy MS (2002). Biosolubilization of poorly soluble rock phosphates by Aspergillus tubingensis and Aspergillus niger. Bioresource Technol 84: 187-189.

3. MINFAL (2010). Agricultural Statistic of Pakistan. Ministry of food, Agriculture and livestock (Economic Wing), Islamabad pp 18-19.

4. GOP. Economic Survey Govt. of Pakistan (2004-2005), Finance Division, Economic Advisory Wing, Islamabad, Pakistan. Pp 8.

5. Ahmad M, Ahmad R \& Rehman AU (2007). Crowding stress tolerance in maize hybrid. http://www.dawn.com/.

6. Khan MS, Zaidi A \& Ahmad E (2014). Mechanism of phosphate solubilization and physiological functions of phosphate solubilizing microorganisms, In: Phosphate Solubilizing Microorganisms: Principles and application of microphos technology. J Springer Inter Publishing Switzerland, Switzer Land 31: 62. doi:10.1007/978-3-319-08216-5_2.

7. Goldstein AH (1986). Bacterial solubilization of mineral phosphates: historical perspectives and future prospects. Am J Altern Agricult 1: 57-65.

8. Fernandez L, Zalba AP, Gomez \& Sagardoy MA (2007). Phosphatesolubilization activity of bacterial strains in soil and their effect on soyabean growth under greenhouse conditions. Biol Fert Soils 43: 803-805.

9. Zou KD, Binkley \& Doxtadar KG (1992). New methods for estimating gross $P$ mineralization rates in soils. Plant Soil 147: 243-250.

10. Mehta P, Walia A, Kulshrestha S, Chauhan A \& Shirkot CK (2014). Efficiency of plant growth-promoting P- solubilizing Bacillus circulans CB7 for enhancement of tomato growth under net house conditions. J Basic Microb 53:112.

11. Khan A, Jilani A, Akhter G, Naqvi MS \& Rasheed M (2009). Phosphorus solubilizing Bacteria; occurrence, Mechanisms and their role in crop production, J Agric Biol Sci 1: 48-58.

12. Qureshi M\A, Ahmad ZA, Akhtar N, Iqbal A, Mujeeb F \& Shakir MA (2012):. Role of phosphate solubiliing bacteria (PSB) in enhancing $\mathrm{p}$ availability and promoting cotton growth. The J of Animal \& Plant Sci 22(1): 204-210.

13. Hilda R \& Fraga R (1999). Phosphate solubilizing bacteria and their role in plant growth promotion. Biotechnol Adv 17: 319-359.

14. Wani PA,Khan MS\& Zaidi A (2007). Synergistic effects of the inoculation with nitrogen fixing and phosphatesolubilizing rhizobacteria on the performance of field grown chickpea. $J$ Plant Nutr Soil Sc 170: 283-287.

15. Kim KY, Jordan D \& Krishnan HB (1997). Rahnellaaqualitis, a bacterim isolated from soybean rhizosphere, can solubilize hydroxyapatite. FEMS Microbiol Lett 153: 273-277.

16. Chen YP, Rekha PO, Arun AB, Shen FT, Lai WA \& Young CC (2006). Phosphate solublizing bacteria from subtropical soils and their tricalciumsolublizing abilities, Appl Soil Ecol 34: 33-41.

17. Steel RGD \& Torrie JH (1980). Principles and procedures of statistics. A biometrical approach. McGraw-Hill, New York, NY.

18. Han HS \& Lee KD (2005). Phosphate and Potassium Solubilizing Bacteria effect on Mineral Uptake, Soil Availability and Growth of Eggplant. Res J of Agri and Biol Sci 1(2): 176-180.

19. Panhwar QA, Radziah O, Zaharah AR, Sariah M \& Razi IM (2011). Role of phosphate solubilizing bacteria on rock phosphate solubility and growth of aerobic rice. J Environ Biol 32: 607-612. 